\title{
Multi-Functional Land Use Is Not Self-Evident for European Farmers: A Critical Review
}

\begin{abstract}
Jaap J. Schröder ${ }^{1}$, Hein F. M. Ten Berge ${ }^{1 *}$, Francesca Bampa ${ }^{2}$, Rachel E. Creamer ${ }^{2}$, Juan V. Giraldez-Cervera ${ }^{3}$, Christian B. Henriksen ${ }^{4}$, Jørgen E. Olesen ${ }^{5}$, Michiel Rutgers ${ }^{6}$, Taru Sandén ${ }^{7}$ and Heide Spiegel ${ }^{7}$

${ }^{1}$ Agrosystems Research, Plant Sciences Group, Wageningen University and Research, Wageningen, Netherlands, ${ }^{2}$ Soil Biology Group, Environmental Sciences, Wageningen University and Research, Wageningen, Netherlands, ${ }^{3}$ Hydrology and Agricultural Hydraulics Group, University of Cordoba, Cordoba, Spain, ${ }^{4}$ Department of Plant and Environmental Sciences, University of Copenhagen, Frederiksberg, Denmark, ${ }^{5}$ Department of Agroecology, Aarhus University, Tjele, Denmark, ${ }^{6}$ National Institute for Public Health and the Environment, Bilthoven, Netherlands, ${ }^{7}$ Department for Soil Health and Plant Nutrition, Institute for Sustainable Plant Production, Austrian Agency for Health and Food Safety, Vienna, Austria
\end{abstract}

\section{OPEN ACCESS}

Edited by:

Maria Luz Cayuela,

Spanish National Research

Council, Spain

Reviewed by:

Felicity Victoria Crotty

Royal Agricultural University,

United Kingdom

Eduardo Gomes,

Universidade de Lisboa, Portugal

*Correspondence:

Hein F. M. Ten Berge

hein.tenberge@wur.nl

Specialty section:

This article was submitted to

Soil Processes,

a section of the journal

Frontiers in Environmental Science

Received: 23 June 2020

Accepted: 14 August 2020

Published: 18 September 2020

Citation:

Schröder JJ, Ten Berge HFM,

Bampa F, Creamer RE,

Giraldez-Cervera JV, Henriksen CB,

Olesen JE, Rutgers M, Sandén T and

Spiegel H (2020) Multi-Functional

Land Use Is Not Self-Evident for

European Farmers: A Critical Review.

Front. Environ. Sci. 8:575466

doi: 10.3389/fenvs.2020.575466
Soils perform more functions than primary productivity. Examples of these functions are the recycling of nutrients, the regulation and purification of water, the regulation of the climate, and supporting biodiversity. These abilities are generally referred to as the soil quality. Soil management that favors primary productivity may have positive and negative impacts on the other functions, and vice versa, depending on soil and climatic conditions. All these functions are under pressure, particularly in intensive agriculture. In the absence of mandatory regulations, most European farmers give limited attention to other functions than primary productivity in spite of recommendations by scientists, society and policy makers to acknowledge the ecosystem services provided by soils. The present paper analyses the underlying causes of this limited attention for the multi-functionality of soils by farmers. It is concluded that their focus on primary productivity may stem from (1) insufficient visible proof for soil degradation and benefits of preventive measures over curative measures, (2) limited awareness or conviction of long-term synergies, (3) insufficient remuneration of ecosystem services by society or compensation of yield penalties in favor of these services, (4) lacking trustworthy knowledge about and support for multi-functional soil management, and (5) absence of incentives and regulations on soil management and their enforcement. All these shortcomings need to be addressed by advisors, scientists, and policy makers, whilst acknowledging the need for underpinning and differentiation of incentives and regulations.

Keywords: land management, primary productivity, soil health, soil quality, soil degradation, soil function, ecosystem services

\section{INTRODUCTION}

Around $40 \%$ of the global land area is devoted to agriculture. In the European Union (EU), too, this share amounts to $43 \%(\mathrm{FAO}, 2018)$. Scientists and policy makers emphasize that this vast area of land performs many functions in addition to primary productivity (Keestra et al., 2016) and that this multi-functionality is under pressure (Stolte et al., 2016; EU, 2019). These other functions 
next to primary productivity (PP) include inter alia the capacity of soils to (1) recycle nutrients from different kinds of by-products (nutrient cycling, NC), (2) regulate the quantity and quality of downstream water (water regulation, WR), (3) regulate the global climate (climate regulation, CR), and (4) provide habitats for soil life as well as aboveground biodiversity (BD) (Schulte et al., 2014). Concerns about these functions and the associated pressure on ecosystem services are reflected in the EU Common Agricultural Policy (CAP), which has evolved over time toward integration of a wider range of environmental issues, including the need to tackle climate change and to manage natural resources in a sustainable manner (EU, 2018a).

However, attention for the multi-functionality of soils remains limited, at least in terms of farmers' uptake and adoption of alternative farming practices (Kertesz and Maderasz, 2014; Virto et al., 2015; EU, 2017). Organic farming and conservation agriculture exhibit a certain awareness of the multi-functionality of soils [e.g., Hobbs et al. (2008), Sandhu et al. (2010)] but currently amount to only 6 and 26\% of the total European agricultural area, respectively (Kassam and Friedrich, 2011; Kertesz and Maderasz, 2014; FAO, 2017; EU, 2018b,c). The preponderant prioritization of PP over other functions was confirmed in 16 local workshops ran in 2015-2016 across Europe. These workshops included 212 farmers, most of them (69\%) originating from Atlantic and Lusitanian environmental zones (Metzger et al., 2005) and generally (74\%) active as arable farmers (O'Sullivan et al., 2018; Sturel et al., 2018; Bampa et al., 2019). Each participant was asked to assign 15 points to the aforementioned five functions of soils to which 177 of them $(83 \%)$ responded (Table 1 ). With the exception of a few individuals, farmers prioritized PP. Attention for other functions than primary productivity diminished in the order of WR, NC, $\mathrm{BD}$, and last CR. No distinct differences were observed between environmental zones. The presence of livestock on farms did not affect the prioritization (Table 1). The smaller attention to other functions than to PP justifies a closer look at possible reasons why farmers are reluctant to adjust the management of their soils. We find it questionable to assume that multifunctional land use brings only win-win's to farmers and society, as recently implied by a group of European scientists and endorsed by the President of the European Commission (Veerman et al., 2020, p. 20 ). We feel that the need for nuances is even greater now that the concept of soil quality is getting gradually replaced by the even more unspecified concept of soil health. The aim of the present paper therefore is to take stock of dilemmas and identify what is needed for multi-functional management.

\section{SYNERGIES AND CONFLICTS}

\section{Primary Productivity Vis a Vis Other Functions}

Even if $\mathrm{PP}$ is the farmer's main concern, it is tempting to think of a soil as a perfectly balanced, healthy, living organism supplying water, aeration, nutrients and pest suppression to crops, perfectly timed and in the required amounts, whilst buffering adverse impacts on the surrounding air and water
(Doran and Zeiss, 2000; Brussaard et al., 2007; Kibblewhite et al., 2008; EU, 2019). True, organisms need to be nurtured, and the application of organic residues indeed stimulates soil life that may suppress pests and liberate nutrients in support of crops (D'Hose et al., 2018). Moreover, inputs of organic matter into the soil could in the longer term help to enhance soil organic carbon (SOC) sequestration, up until a new equilibrium between the annual supplementation and decay is reached (Johnston et al., 2009). Organic matter additions may also improve soil structure and, consequently, the availability of water, air and nutrients. Such changes may gain significance in view of more frequent weather extremes under projected climate change (Allan and Soden, 2008).

In this representation, $\mathrm{PP}, \mathrm{NC}, \mathrm{WR}, \mathrm{CR}$, and $\mathrm{BD}$ all appear to mutually reinforce each other at first glance. From that perspective, disruption of the soil structure by tillage, application of pesticides, and the substitution of manures and other organic amendments by mineral fertilizers appear to undermine the delicate concert of functions. Refraining from intensive tillage may indeed be beneficial for crop yields in environments where there is a need for conserving water or protecting soils from erosion through improved infiltration, but can reduce yields elsewhere (Holland, 2004; van den Putte et al., 2010; Pittelkow et al., 2015; Sandén et al., 2018). Reduced tillage helps to save fossil fuel, but may require greater inputs of herbicides to control perennial weeds (Chauhan et al., 2012). Meta-analyses indicate that refraining from pesticides costs around $25 \%$ yield, which cannot always be compensated by widening rotations and applying other measures that may help to increase the resilience of agroecosystems (de Ponti et al., 2012; Seufert et al., 2012). In general, the use of pesticides apparently pays off for the farmer, despite its negative side-effects on natural enemies and nontarget organisms and potential human health effects. There is also little if any evidence in the scientific literature that pesticides or tillage disrupt soil life to an extent that negatively affects the decomposition of organic residues and, as a consequence, the availability of nutrients to crops. To the contrary, switching-off the activity of particular types of soil life by applying specific agrochemicals (such as nitrification inhibitors) may even improve the availability of nutrients from organic residues (Edmeades, 2004), whereas reduced tillage may, at least initially, reduce rather than enhance the net mineralization from organic residues (van den Bossche et al., 2009), despite its positive effect on the survival of earthworms (Briones and Schmidt, 2017). Retention of crop residues may be good for the maintenance of the SOC content, nutrients and structure of soils (Lehtinen et al., 2014; Spiegel et al., 2018), whether or not via stimulated soil life. It can at the same time deprive farmers from income if they could have sold these residues or used them as feed for livestock. Farmers are fully aware of the need to replenish organic matter in soils [e.g., Sturel et al. (2018), Bampa et al. (2019)], but the positive effect of organic matter on crop yields is limited and often questionable (Loveland and Webb, 2003; Hijbeek et al., 2017) and there is a limit to how much SOC can be stored (Castellano et al., 2015). Farmers therefore know that there is no need to apply as much organic matter as possible, regardless of the positive effects on soil life and carbon $(C)$ sequestration. Farmers also know that 
TABLE 1 | Average prioritization of soil functions by 177 farmers across Europe, as reflected by their allocation of 15 points to primary productivity (PP), water regulation (WR), climate regulation (CR), nutrient cycling (NC), or the provision of habitats for biodiversity (HP) (Sturel et al., 2018; source: O'Sullivan et al., 2018).

\begin{tabular}{|c|c|c|c|c|c|c|c|}
\hline \multirow[t]{2}{*}{ Environmental zone/presence of livestock } & \multirow[t]{2}{*}{ Number of respondents } & \multicolumn{6}{|c|}{ Soil function } \\
\hline & & PP & WR & CR & NC & BD & Sum \\
\hline Atlantic and Lusitanian & 122 & 4.1 & 3.1 & 2.3 & 2.9 & 2.6 & 15 \\
\hline Continental and Pannonian & 32 & 4.3 & 3.2 & 2.3 & 3.0 & 2.3 & 15 \\
\hline Mediterranean & 23 & 4.7 & 3.0 & 2.6 & 2.0 & 2.7 & 15 \\
\hline Without livestock & 131 & 4.3 & 3.0 & 2.3 & 2.8 & 2.5 & 15 \\
\hline With livestock & 46 & 4.0 & 3.2 & 2.5 & 2.6 & 2.7 & 15 \\
\hline TOTAL & 177 & 4.2 & 3.1 & 2.4 & 2.8 & 2.6 & 15 \\
\hline
\end{tabular}

crops themselves produce considerable amounts of residues rich in organic matter, provided sufficient nitrogen $(N)$ is applied. They are aware that $N$ fertilizers do not only increase marketable yields but also the production of crop residues. Consequently, $N$ application generally increases organic matter additions to soils and this contribution is only slightly counteracted by an enhanced decay of that organic matter due to narrower $C$ to $N$ ratios (Russell et al., 2009). Statements of Mulvaney et al. (2009), suggesting that the mere use of mineral $\mathrm{N}$ fertilizer reduces soil organic matter instead of increasing it, were criticized by Powlson et al. (2010). The latter showed that Mulvaney's dataset was extremely biased. Liming, on the other hand, may stimulate the oxidation of soil organic matter via $\mathrm{pH}$ effects, and may thus offset the sequestration of SOC. This constitutes a dilemma wherever crop yields are stronger limited by too low a $\mathrm{pH}$ than by lack of organic matter.

The use of $N$ as such, regardless whether derived from mineral or organic sources, has a crucial role in the formation of crop yields. Even when perfectly timed and positioned, no individual crop or at least crop rotation as a whole can utilize the total amount of $N$ applied (Schröder et al., 2016). This implies a principal conflict between crop production, and the quality of nearby ground- and surface waters (particularly in terms of nitrate- $N$ ), regardless of differences between crops, soil types, and nutrient application methods (Erisman et al., 2011; Schröder, 2014). Cover cropping also helps to retain soil mineral $N$, but may, in some climates compete with following crops for water and nutrients. Timely establishment of cover crops may reduce the main crop's field duration and thus its yield potential, particularly in cropping systems that most need cover crops to contain the risk of nitrate leaching (Schröder et al., 1996; Vos and van der Putten, 1997). Water quality is generally better where soils and subsoils are conducive to denitrification. Refraining from artificial drainage would therefore help (Coyle et al., 2016; Clague et al., 2019). Undrained soils, however, are less productive and are more at risk of compaction due to trampling by livestock or weight intensity of machinery, presenting yet another dilemma. In drier climates, crop yields and the recovery of nutrients by crops may benefit from irrigation rather than from drainage. However, what is gained there in terms of yield on one farm may be lost on farms downstream or for other functions (e.g., attenuation of too high nitrate concentrations) once water has been used upstream for PP. Calls to conserve existing grassland, or to even extend the share of grass leys in arable rotations constitutes another dilemma. Grasslands are known for their ability to improve the performance of subsequent arable crops [e.g., Nevens and Reheul (2002)], store SOC [e.g., van de Broek et al. (2019)], reduce $N$ leaching [e.g., Schröder et al. (2007)], and foster biodiversity [e.g., van Leeuwen et al. (2019)]. There are, however, limits to the societal demand for grassland-based components in human diets, particularly in view of optimized human diets implying a diminishing need for animal feed, at least in developed countries (van Zanten et al., 2019). In conclusion, many measures with evident positive effects on PP may have detrimental effects on other soil functions and vice versa.

\section{Dilemmas Beyond the Primary Productivity Function}

There are not only dilemmas between the required measures in favor of PP and those needed for other soil functions but also between needs within the suite of those other soil functions. Recycling of nutrients in by-products, including manures, is sooner or later an absolute must (Schröder, 2014). However, using manures as a source of nutrients can be more detrimental to the quality of air and water than using mineral fertilizers, as revealed by their long term relative $N$ replacement values below $100 \%$ (Schröder, 2014). The application of manures may, for instance, be linked to a greater production of the greenhouse gas (GHG) nitrous oxide (Christensen, 1985; Thompson, 1989; Ellis et al., 1998; Rochette et al., 2000; Velthof et al., 2003; McGeough et al., 2012; Bos et al., 2017). GHG emission in terms of $\mathrm{CO}_{2}$ equivalents may also increase when tillage is reduced or totally refrained from (Palma et al., 1997; Lehtinen et al., 2014; Spiegel et al., 2014), although the over-all effects of manuring and tillage on nitrous oxide losses are highly context specific, depending on soil and climate conditions. Besides, from a GHG reduction perspective it may be better to use organic residues such as cereal straw as a biofuel than to use it as a soil amendment (Powlson et al., 2011). As for $\mathrm{N}$, the "slow release" character of organic residues can be advantageous (e.g., under wet conditions, but can just as well contribute to an untimely mineralization followed by nitrate leaching losses). The consequent risks of these losses can only partly be compensated for by the establishment of cover crops (Schröder et al., 1996, 1997). As the kg's $N$ per kg of phosphorus $(P)$ in most organic residues are lower than the 
required ratio of $N$ and $P$ from the perspective of crop demand, too much $P$ would be applied if input rates of (e.g., manures were tuned to the $N$ demand of crops). This would eventually lead to $P$ accumulation putting the quality of water bodies at risk (Schröder, 2005), constituting a conflict between NC and WR. To avoid that, supplemental $N$ inputs by mineral $N$ fertilizers or biological $N$ fixation (BNF) by leguminous green manures are needed. The latter option claims additional land area at the expense of wilderness and its associated biodiversity, at least in temperate climates where leguminous cover crops grown after main crops can rarely fix sufficient $N$ to cover demands of the whole rotation (de Notaris et al., 2019; Schröder, 2019). Major synergies and conflicts, as discussed above, are summarized in the right hand side of Table 2 . The many dilemmas further contribute to the complexity of multi-functionality.

\section{Soil Quality?}

It is evident that soil characteristics, climatic conditions and management practices that are good for one function are not always good for other functions. From this perspective, there is no such thing as one unique soil quality providing all functions at their highest level (Letey et al., 2003; Sojka et al., 2003; Bünemann et al., 2018), not even at the individual field level, since it also depends on the production system in focus. Therefore, any suggestion of a categorical and ubiquitous synergy of functions is too simplistic (Pilgrim et al., 2010; Power, 2010; Bünemann et al., 2018; Sandén et al., 2018; Ten Berge et al., 2019). In general, farmers will seriously weigh trade-offs when considering the uptake of measures (Giller et al., 2009; Valbuena et al., 2012; van den Broeck et al., 2013). Most farmers are aware of conflicts and this may explain why they adhere to practices with a proven yield promoting record and avoid measures that can jeopardize, let alone limit their income (Bampa et al., 2019). This is particularly the case as long as the resultant functions cannot be marketed in the form of appreciated ecosystem services and unpaid trade-offs are more forthcoming than long-term financial benefits.

\section{FUNCTION LOSS: HOW MUCH AND WHERE?}

\section{How Urgent Are Measures?}

From a PP perspective, a soil can be qualified as good if it provides sufficient water, aeration, nutrients, and if it suppresses pests and diseases. Soils can lose these functions through, for instance, compaction, erosion, acidification, organic matter loss, or contamination with pests, heavy metals and organic pollutants (Virto et al., 2015; Stolte et al., 2016; Ten Berge et al., 2017; Rodriguez et al., 2018). Degradation tends to take place slowly and without immediate effects, often eluding observation. Unfortunately, returns on investments in soil quality (i.e., noticeable improvements resulting from a more soilfriendly management) also tend to come slowly. Moreover, if deterioration of soil quality is discerned at all, farmers have several options to compensate for that loss by technological measures (e.g., deeper tillage, more irrigation, or artificial drainage, and increased inputs of agro-chemicals, including pesticides, fertilizers, and inhibitors). Apparently, the costs of these measures are often believed to be lower than the costs of preventive or conservation practices.

As far as the potential loss of multi-functionality is concerned, it can be argued that loss of a function in one place (e.g., on agricultural land) can be seen as insignificant as long as it is compensated elsewhere (e.g., off-farm), in particular when considering that some fields and landscapes are better suited for specific functions than others. Note, that this still means that each spatial entity (field, farm, region, or country) should probably provide an amount of less profitable soil functions for a balanced provision of the total set of services, rather than passing on the less lucrative services to other places or to future generations. Note, that at local scale the details and specifications of some soil functions may be so strongly linked to other functions that it can be impossible to substitute them elsewhere without losing the very benefits of that function. Examples are aspects of WR for the benefit of crop production itself (probably explaining the relatively high appreciation of the WR function, Table 1), or meadow bird conservation within grassland-based dairy systems (i.e., the need to preserve grasslands), or soil life preservation in favor of natural enemies of crop pests. In practice, this requires knowledge on the quantitative relationships between soil functions and management practices when society asks for an appropriate provision of specific functions. The above considerations are related to the sharing-sparing debate (Balmford et al., 2018; Phalan, 2018). The spatial interchangeability of functions makes it difficult to accurately assess to what extent there is a net loss or not (Stürck and Verburg, 2017).

\section{Evidence Base}

At a global level, about $25 \%$ of all soils are deemed to suffer from degradation as a result of compaction, erosion, loss of organic matter, and contamination [e.g., FAO (2015)]. European soils are also suspected of degradation (Montanarella, 2007). It is challenging, however, to translate this multi-faceted and qualitative concept of a gradually declining soil quality into quantitative terms of crop yields and financial penalties for both farmers and society as a whole (Bindraban et al., 2012). Both tax payers and consumers will probably want to see evidence before paying for alternative farming practices for the sake of multi-functionality. The farmers themselves may want to see some proof before being curtailed in their management options, regardless whether they are financially compensated or not. The indiscriminate nature of universal directives imposed on all farmers based on a too rigid application of the precautionary principle is questionable (Hanekamp et al., 2005), as is the desire to create a so-called level playing field whilst disregarding differences in local needs (Schröder et al., 2004). Undoubtedly, there are plenty of local cases where soils are at risk of irreversible degradation. However, upscaling these observations to a wider area without additional validations can produce unsupported conclusions (Bindraban et al., 2012), as demonstrated for erosion risks in Europe [e.g., Cerdan et al. (2010)] or the perceived loss of soil organic matter in The Netherlands (Reijneveld et al., 2009). Besides, where a decline of soil organic matter is evident, policy makers should make a distinction between changes resulting 
TABLE 2 | Links between threats of soil quality characteristics, management practices, and their estimated effect on soil functions (PP, primary productivity; WR, water regulation; CR, climate regulation; NC, nutrient cycling; BD, provision of habitats for biodiversity) and potential indicators (RUSLE, Revised Universal Soil Loss Equation; LULUCF, Land Use; Land-Use Change and Forestry; O.M., soil organic matter; PAC, polycyclic aromatic hydrocarbons) of these threats and functions (green, positive effect of practice; red, negative effect; amber, variable effect; GHG, greenhouse gases; NUE, nutrient use efficiency).

\begin{tabular}{|c|c|c|c|c|c|c|c|c|c|c|c|}
\hline \multicolumn{6}{|c|}{ Threats of soil functions: } & \multirow[t]{3}{*}{ Managment practices } & \multicolumn{5}{|c|}{ Effects of practice on soil functions: } \\
\hline \multirow[t]{2}{*}{ Erosion } & \multirow[t]{2}{*}{ Compaction } & \multirow[t]{2}{*}{ O.M. loss } & \multirow[t]{2}{*}{ Acidification } & \multicolumn{2}{|c|}{ Contamination: } & & \multirow[t]{2}{*}{ pp } & \multirow[t]{2}{*}{ WR } & \multirow[t]{2}{*}{ CR } & \multirow[t]{2}{*}{ NC } & \multirow[t]{2}{*}{ BD } \\
\hline & & & & chemical & biological & & & & & & \\
\hline \multirow[t]{2}{*}{+} & + & $=$ & & & & Artificial drainage & + & +- & + & + & + \\
\hline & & & & & & Field traffic as such & +- & & & +- & \\
\hline \multirow[t]{9}{*}{+} & + & + & & & & Grassland preservation & & + & +- & + & + \\
\hline & + & & & & + & Crop rotation, incl. leys & + & +- & & + & +- \\
\hline & & & & & & Biological $\mathrm{N}$ fixation & + & & & + & \\
\hline & + & & & & & Tillage & +- & +- & +- & + & \\
\hline & + & & + & & & Liming & + & +- & & + & + \\
\hline & & + & & & & Manuring & + & & & & + \\
\hline & & & & & & Mineral N fertilizer use & + & & + & + & \\
\hline & & & & & & Irrigation & + & +- & & + & + \\
\hline & & & & & + & Pest control & + & +- & & + & \\
\hline+ & + & + & & & & Crop residue retention & +- & + & +- & +- & + \\
\hline+ & + & + & & & & Cover cropping & + & +- & + & +- & + \\
\hline \multicolumn{6}{|c|}{ Indicators of threats: } & & \multicolumn{5}{|c|}{ Indicators of functioning: } \\
\hline $\begin{array}{l}\text { RUSLE, } \\
\text { soil loss }\end{array}$ & $\begin{array}{l}\text { wheel } \\
\text { load (WLCC), } \\
\text { penetration } \\
\text { resistance }\end{array}$ & $\begin{array}{l}\text { LULUCF, } \\
\text { o.m.\% }\end{array}$ & $\mathrm{pH}$ & $\begin{array}{l}\text { heavy metal, } \\
\text { PACs, } \\
\text { hormone } \\
\text { concentration }\end{array}$ & $\begin{array}{l}\text { incidence of pest, } \\
\text { diseases, weeds; } \\
\text { biodiversity }\end{array}$ & & yield & $\begin{array}{l}\text { qual \& } \\
\text { quan, } \\
\text { sedime }\end{array}$ & GHG & NUE & biodiversity \\
\hline
\end{tabular}

from inadequate management (e.g., insufficient supplementation of organic matter and/or practices promoting its decomposition) within arable land use itself (Virto et al., 2015) and the changes resulting from long-term land use change (e.g., conversion of grasslands into arable land). Moreover, as far as the CR function is concerned, the negative impact of the latter changes should be weighed against the positive impact of reverse land use change such as the afforestation of former agricultural land (Luyssaert et al., 2010) or the restoration of wetlands (Erwin, 2009).

Soil compaction, too, is regarded as a serious soil threat (Stolte et al., 2016; Ten Berge et al., 2019). This fear seems justified in view of the increased machine weights and wheel pressures (Chamen et al., 1992). Compaction induces a need for increased inputs of nutrients and water to maintain crop yields and increased energy requirements for tillage and the harvest of lifted crops. Importantly, the environmental impact of compaction extends beyond that of the compacted site, for example through increased water pollution resulting from runoff (Soane and Van Ouwerkerk, 1995). However, statements on the extent of compaction in to which European soils are compacted, are thus far largely based on the mapping of risks and susceptibilities rather than detailed surveys (Jones et al., 2003; Montanarella, 2007; Schjønning et al., 2018). A more precise assessment of the present state is therefore required.

There is less reason to doubt the degraded state of agroenvironments, when it comes to biodiversity. Biodiversity decline is not just a local phenomenon needing local management adjustments, but undeniably a pan-European issue (Donald et al., 2001; Kleijn et al., 2009; Stoate et al., 2009; van Dyck et al., 2009). The previous references pertain to aboveground biodiversity. It is plausible that the less visible belowground biodiversity has in many cases also declined (Tsiafouli et al., 2015). The implications of this loss for soil services other than biodiversity as a goal in itself, i.e., the intrinsic value of nature, is, however, not yet fully understood e.g., Setälä et al. (2005). There is thus a considerable need for up-to-date evidence, convincing society and farmers of the necessity to change management whenever the intrinsic value of biodiversity is not sufficiently persuasive to pursue its preservation.

\section{CARROTS AND STICKS}

Decision making on multifunctional land management is extremely challenging, also because it is getting more and more difficult to distinguish between objective and tainted information nowadays. In an attempt to assist farmers in long term sustainable management of their soil and land the Soil Navigator decision support system for assessing and optimizing soil functions was recently developed in the Horizon 2020 LANDMARK project (Debeljak et al., 2019). For each of the five soil functions multicriteria decision models featuring a set of attributes, integration rules and threshold values were developed, calibrated, and validated using expert knowledge and data mining (Sanden et al., 2019; Trajanov et al., 2019; van de Broek et al., 2019; van Leeuwen et al., 2019; Wall et al., 2020). Subsequently, the five models were integrated into a decision support system. The Soil Navigator helps to visualize synergies and trade-offs and gives management recommendations. However, farmers also need incentives for adjusting their management in favor of multi-functionality beyond that of the PP function, unless they would benefit from these adjustments via increased yields, reduced costs or other benefits in lieu, such as reduced labor requirements. The disintegration of originally mixed farming systems into subsystems where the production, processing and consumption of crops by livestock and direct human 
consumption have become spatially separated (captured in words such as specialization, upscaling, urbanization, and globalization) is probably neither conducive to internalizing multi-functionality and carefully weighing the possible macro-financial benefits of a more integral approach. Disintegration allows many arable farmers, for instance, to decline organic fertilizers and improve their own farm's apparent resource use efficiency by using mineral fertilizers instead, be it at the expense of nutrient use efficiency at higher spatial scales and violation of the need to close nutrient cycles (Schröder, 2019). Specialized arable farmers do not consider nutrient recycling as selfevident without financial compensation, as opposed to mixedfarmers for whom the presence of organic fertilizers is a daily reality. Landless livestock farmers, in turn, prefer the purchase of grain-based concentrates to feed their animals over less digestible by-products. In more general terms, disintegration provides stimuli to leave particular services to society as a whole.

Where additional institutions ("markets") and compensations ("carrots") fail to acknowledge and appreciate the multifunctionality of soils, deterrents ("sticks") in the form of directives and regulations may work. Violation of prescribed management practices is then penalized through additional taxes or fines. Lack of "sticks" may thus be another reason why farmers have as yet not embraced multi-functional land management. Carrots and sticks are generally linked to a mandatory application of preferred practices ("do's") and banning of undesired practices ("don'ts"), and not to quantifiable abatement of threats or to measurable functionalities. Enforcement thus relies on means-oriented indicators (the "management practices" column in Table 2) rather than goal-oriented indicators (the "soil function" columns in Table 2). Goal-oriented indicators offer more clear motivations for farmers and directly reflect the basic rationale behind policies. However, the measurement of goal-oriented indicators often takes serious efforts and will generally reveal where measures make sense and where they do not. There is often also a lag-time of many years before changes in management result in measurable effects on key soil quality or environmental indicators. In contrast, meansoriented indicators are often part of existing farm data and can address several underlying goals simultaneously. Unfortunately, their effectiveness in terms of fulfilling the ultimate targets is affected by uncertainties due to disregarded factors including weather, and interactions between factors. However, meansoriented indicators respond fast, often instantaneously, they can be easily recorded if not already available, and are thus directly attributable to a particular field or farm and the ones in charge of managing that field or farm (Schröder et al., 2004). Livestock density is a typical example of such a blunt indicator. It is at best a proxy of the likelihood of other services provided, but not a guarantee. Burton and Schwartz (2013) therefore criticize activity-oriented remuneration schemes and propose a framework for result-oriented schemes instead. Farmers, however, may dislike the principle uncertainty of their efforts in terms of measurable results and, thus, financial compensation. Where the measurement of results is hard to achieve, model-based predictions of results may represent an preferable alternative (Bartkowski et al., 2019). The combination of means-oriented (activity-based) and goal-oriented (result-based) indicators might well be a way forward to overcome disadvantages of too much focus on either activity-based or result-based indicators. Bünemann et al. (2018) feel that there is still unexploited room to improve the informative power of soil quality indicators, underlying means-oriented and goal-oriented indicators. However, Ten Berge et al. (2019) argue that soil quality-related indicators have only limited value for decision making and evaluation, given their relatively weak relationship with aspired ecosystem services. Examples in the present paper confirm the position of Ten Berge et al. (2019).

Vrebos et al. (2017) showed that the limited availability of effective sticks and carrots and their attendant indicators is indeed an additional explanation for the restricted implementation of multi-functional land management by farmers in Europe. A possible solution could be to integrate payment for sustaining soil functions in national or supranational agricultural support schemes, such as the green direct payments or the agri-environment schemes of the CAP and use locally adapted and validated soil function models to document the effect of applied management practices (Bartkowski et al., 2019; Schulte et al., 2019). Whatever the character of eventual regulations will be, a much better interaction between scientists, policy makers, and stakeholders is key for full adoption of multifunctional soil management (Bouma, 2019).

\section{CONCLUSIONS}

Agricultural land use in Europe pays limited attention to multifunctionality. Many farmers seem not concerned about the long-term ability of their soils to produce crops, let alone the production of other services. And if they are, they are reluctant to change the management as long as they are not forced to or financially rewarded for these additional services and the potentially negative implications for crop yields. But even then they may feel in the dark about what exactly to do. Actions directed at soil quality and soil health then remain long shots, unless farmers have access to reliable information.

The existing literature shows that it is not possible to manage agricultural soils in a way that all soil functions will be simultaneously delivered at the highest locally attainable level. Likewise, it is not easy to quantify the long-term implications of land management and soil degradation for soil functions, amongst which is primary productivity. This constitutes a challenge to influence the management beyond that providing short-term benefits for farmers in terms of crop yield and income. It also makes it difficult to assess the remuneration that the society should offer to farmers for producing additional services. Advice and assessments directed at such multi-functional land management are currently often tentative and, almost inevitably, expressed in terms of do's and don'ts, instead of the ultimate goals. Policies including these do's 
and don'ts tend to limit the management options for farmers. It is therefore up to scientists to fortify the evidence base showing the causality between farming practices, soil threats (i.e., specification of "soil quality" and "soil health" and the need for their conservation), soil functions and soil services, including trade-offs and synergies. In parallel and founded on a corroborated evidence base, it is up to policy makers to pave the way for incentivisation through a set of policy measures and criteria aiming at a better consideration of the multi-functionality of soils. Considering the differences across Europe in soils and climate, "one size fits all" regulations are inappropriate. Differentiation of regulations would acknowledge that specific practices are simply not needed or inapplicable in one place, whereas they are a precondition elsewhere. Underpinned differentiation could increase the support by farmers and challenge them to contribute to services that suit them best in view of local soil characteristics, landscapes, climate, markets, the availability of equipment, sources of information and capital.

\section{REFERENCES}

Allan, R., and Soden, B. (2008). Atmospheric warming and the amplification of precipitation extremes. Science 321, 834-843. doi: 10.1126/science.1160787

Balmford, A., Amano, T., Bartlett, H., Chadwick, D., Collins, A., Edwards, D. P., et al. (2018). The environmental costs and benefits of high yield farming. Nat. Sustain. 11, 477-485. doi: 10.1038/s41893-018-0138-5

Bampa, F., O’Sullivan, L., Madena, K., Sandén, T., Spiegel, H., Bugge Henriksen, K., et al. (2019). Harvesting European knowledge on soil functions and land management using multi-criteria decision analysis. Soil Use Manage. 35, 6-20. doi: $10.1111 /$ sum. 12506

Bartkowski, B., Droste,N., Liess, M., Sidemo-Holm, W., Weller, U., and Brady, M.V. (2019). "Implementing result-based agri-environmental payments by means of modelling," in UFZ Discussion Papers, Helmholtz Zentrum fuer Umweltforschung, (Leipzig), 1-28.

Bindraban, P. S., van der Velde, M., Ye, L., van den Berg, M., Materechera, S., Kiba, D. I., et al. (2012). Assessing the impact of soil degradation. Curr. Opin. Env. Sust. 4, 478-488. doi: 10.1016/j.cosust.2012.09.015

Bos, J. F. F. P., Ten Berge, H. F. M., Verhagen, J., and van Ittersum, M. K. (2017). Trade-offs in soil fertility management on arable farms. Agric. Syst. 157, 292-302. doi: 10.1016/j.agsy.2016.09.013

Bouma, J. (2019). How to communicate soil expertise more effectively in the information age when aiming at the UN sustainable development goals. Soil Use Manage. 35, 32-38. doi: 10.1111/sum. 12415

Briones, M. J. I., and Schmidt, O. (2017). Conventional tillage decreases the abundance and biomass of earthworms and alters their community structure in a global meta-analysis. Glob. Change Biol. 23, 4396-4419. doi: $10.1111 /$ gcb. 13744

Brussaard, L., de Ruiter, P. C., and Brown, G. G. (2007). Soil biodiversity for agricultural sustainability. Agr. Ecosyst. Environ. 121, 233-244. doi: 10.1016/j.agee.2006.12.013

Bünemann, E. K., Bongiorno, G., Bai, Z., Creamer, R. E., de Deyn, G., de Goede, R., et al. (2018). Soil quality: a critical review. Soil Biol. Biochem. 120, 105-125. doi: 10.1016/j.soilbio.2018.01.030

Burton, R. J. F., and Schwartz, G. (2013). Result-oriented agri-environmental schemes in Europe and their potential for promoting behavior change. Land Use Pol. 30, 628-641. doi: 10.1016/j.landusepol.2012.05.002

Castellano, M. J., Mueller, K. E., Olk, D. C., Sawyer, J. E., and Six, J. (2015). Integrating plant litter quality, soil organic matter stabilization, and the carbon saturation concept. Glob. Change Biol. 21, 3200-3209. doi: 10.1111/gcb.12982

Cerdan, O., Govers, G., Le Bissonnais, Y., van Oost, K., Poesen, J., Saby, N., et al. (2010). Rates and spatial variation of soil erosion in Europe:

\section{AUTHOR CONTRIBUTIONS}

JS and HTB conceptualized the paper. JS wrote the first draft, integrated the additions, and comments of HTB, FB, RC, JG-C, $\mathrm{CH}$, JEO, MR, TS, and HS. All authors contributed to the article and approved the submitted version.

\section{FUNDING}

This study was conducted as part of the LANDMARK (LAND Management: Assessment, Research, Knowledge Base, www. landmark2020.eu) project. LANDMARK has received funding from the European Union Horizon 2020 research and innovation programme under grant agreement No. 635201.

\section{ACKNOWLEDGMENTS}

The authors thank two reviewers for their valuable comments on an earlier draft of this paper.

a study based on erosion plot data. Geomorphology 122, 167-177. doi: 10.1016/j.geomorph.2010.06.011

Chamen, W. C. T., Vermeulen, G. D., Campbell, D. J., and Sommer, C. (1992). Reduction of traffic-induced soil compaction: a synthesis. Soil Till. Res. 24, 303-318. doi: 10.1016/0167-1987(92)90116-S

Chauhan, B. S., Singh, R. G., and Mahajan, G. (2012). Ecology and management of weeds under conservation agriculture. Crop Prot. 38, 57-65. doi: 10.1016/j.cropro.2012.03.010

Christensen, S. (1985). Denitrification in an acid soil: effects of slurry and potassium nitrate on the evolution of nitrous oxide and on nitrate reducing bacteria. Soil Biol. Biochem. 17, 757-764. doi: 10.1016/0038-0717(85)90129-4

Clague, J. C., Stenger, R., and Morgenstern, U. (2019). The influence of unsaturated zone drainage status on denitrification and redox succession in shallow groundwater. Sci. Total Environ. 660, 1232-1244. doi: $10.1016 /$ j.scitotenv.2018.12.383

Coyle, C., Creamer, R. E., Schulte, R. P. O., O’Sullivan, L., and Jordan, P. (2016). A functional land management conceptual framework under soil drainage and land use scenarios. Env. Sci. Pol. 56, 39-48. doi: 10.1016/j.envsci.2015.10.012

de Notaris, C., Rasmussen, J., Sørensen, P., Melander, B., and Olesen, J. E. (2019). Manipulating cover crop growth by adjusting sowing time and cereal interrow spacing to enhance residual nitrogen effects. Field Crops Res. 234, 15-25. doi: 10.1016/j.fcr.2019.02.008

de Ponti, T., Rijk, B., and van Ittersum, M. K. (2012). The crop yield gap between organic an conventional agriculture. Agric. Syst. 108, 1-9. doi: 10.1016/j.agsy.2011.12.004

Debeljak, M., Trajanov, A., Vladimir Kuzmanovski, V., Schröder, J. J., Sandén, T., Spiegel, H., et al. (2019). A field-scale decision support system for assessment and management of soil functions. Front. Environ. Sci. 7, 115. doi: 10.3389/fenvs.2019.00115

D’Hose, T., Molendijk, L., van Vooren, L., van den Berg, W., Hoek, H., Runia, W., et al. (2018). Responses of soil biota to non-inversion tillage and organic amendments: an analysis on European multiyear field experiments. Pedobiologia 66, 18-28. doi: 10.1016/j.pedobi.2017.12.003

Donald, P. F., Green, R. E., and Heath, M. F. (2001). Agricultural intensification and the collapse of Europe's farmland bird populations. Proc. R. Soc. B. 268, 25-29. doi: 10.1098/rspb.2000.1325

Doran, J. W., and Zeiss, M. R. (2000). Soil health and sustainability: managing the biotic component of soil quality. Appl. Soil Ecol. 15, 3-11. doi: 10.1016/S0929-1393(00)00067-6

Edmeades, D. C. (2004). Nitrification and Urease Inhibitors. Environment Bay of Plenty, Environmental Publication 2004/11. Wakathane, 17. doi: $10.1080 / 00288233.2004 .9513566$ 
Ellis, S., Yamulki, S., Dixon, E., Harrison, R., and Jarvis, S. C. (1998). Denitrification and $\mathrm{N} 2 \mathrm{O}$ emissions from a UK pasture soil following the early spring application of cattle slurry and mineral fertiliser. Plant Soil 202, 15-25. doi: 10.1023/A:1004332209345

Erisman, J. W., van Grinsven, H., Grizzetti, B., Bouraoui, F., Powlson, D., Sutton, M. A., et al. (2011). "The European nitrogen problem in a global perspective," in The European Nitrogen Assessment, eds M. A. Sutton, C. M. Howard, J. W. Erisman, G. Billen, A. Bleeker, P. Grennfelt, H. Grinsven, and B. Grizzetti (Cambridge: Cambridge University Press), 9-31. doi: 10.1017/CBO9780511976988.005

Erwin, K. L. (2009). Wetlands and global climate change: the role of wetland restoration in a changing world. Wetlands Ecol. Manage. 17, 71-84. doi: 10.1007/s11273-008-9119-1

EU (2017). The Future of Food and Farming, Communication from the Commission to the European Parliament, the Council, the European Economic and Social Committee and the Committee of the Regions, Brussels, 29.11.2017 $\operatorname{COM}(2017) 713$ final. Available online at: https://ec.europa. eu/agriculture/sites/agriculture/files/future-of-cap/future_of_food_and_ farming_communication_en.pdf (accessed September 7, 2020).

EU (2018a). Common Agricultural Policy, European Union. Available online at: https://ec.europa.eu/info/food-farming-fisheries/key-policies/commonagricultural-policy/cap-glance_en (accessed September 7, 2020).

EU (2019). "Mission: Caring for soil is caring for life," in Independent Action Group, Mission Board Soil Health and Food, (Brussels: European Commission), 1-40.

EU (2018b). Organic Farming, Agriculture and Rural Development. Available online at: https://ec.europa.eu/agriculture/organic/organic-farming_en (accessed September 7, 2020).

EU (2018c). Share of Total Organic Area in UAA in European Union. Available online at: http://ec.europa.eu/eurostat/statistics-explained/index.php?title= File:Figure_3_Share_of_total_organic_area_in_total_utilised_agricultural_ area_(UAA),_by_country,_2016_(\%25).png (accessed September 7, 2020).

FAO (2015). Status of the World's Soil Resources. Available online at: http://www. fao.org/3/a-i5199e.pdf (accessed September 7, 2020).

FAO (2017). Conservation Agriculture. Available online at: http://www.fao.org/3/ a-i7480e.pdf (accessed September 7, 2020).

FAO (2018). FAOSTAT Land Use data from 2015. Available at: http://www.fao.org/ faostat/en/\#data/EL (accessed September 7, 2020).

Giller, K. E., Witter, E., Corbeels, M., and Tittonell, P. (2009). Conservation agriculture and smallholder farming in Africa: the heretics' view. Field Crops Res. 114, 23-34 doi: 10.1016/j.fcr.2009.06.017

Hanekamp, J. C., Vera-Navas, G., and Verstegen, S. W. (2005). The historical roots of precautionary thinking: the cultural ecological critique and 'The Limits to Growth'. J. Risk Res. 8, 295-310. doi: 10.1080/1366987042000265056

Hijbeek, R., van Ittersum, M. K., Ten Berge, H. F. M., Gort, G., Spiegel, H., and Whitmore, A. P. (2017). Do organic inputs matter-a meta-analysis of additional yield effects for arable crops in Europe. Plant Soil 411, 293-303. doi: 10.1007/s11104-016-3031-x

Hobbs, P. R., Sayre, K., and Gupta, R. (2008). The role of conservation agriculture in sustainable agriculture. Philos. Trans. R. Soc. Lond. B. Biol. Sci. 363, 543-555. doi: $10.1098 /$ rstb.2007.2169

Holland, J. M. (2004). The environmental consequences of adopting conservation tillage in Europe: reviewing the evidence. Agr. Ecosyst. Environ. 103, 1-25. doi: 10.1016/j.agee.2003.12.018

Johnston, A. E., Poulton, P. R., and Coleman, K. (2009). Soil organic matter its importance in sustainable agriculture and carbon dioxide fluxes. Adv. Agron. 101, 1-57. doi: 10.1016/S0065-2113(08)00801-8

Jones, R. J. A., Spoor, G., and Thomasson, A. J. (2003). Vulnerability of subsoils in Europe to compaction: a preliminary analysis. Soil Till. Res. 73, 131-143. doi: 10.1016/S0167-1987(03)00106-5

Kassam, A. and Friedrich, T. (2011). Conservation Agriculture: Principles, Sustainable Land Management and Ecosystem Services, Società Italiana de Agronomia XL Convegno Nazionale, Università degli Studi Teramo, Rome, Italy.

Keestra, S. D., Bouma, J., Wallinga, J., Tittonell, P., Smith, P., Cerdà, A., et al. (2016). The significance of soils and soil science towards realization of the United nations sustainable development goals. Soil 2, 111-128. doi: 10.5194/soil-2-111-2016

Kertesz, A., and Maderasz, B. (2014). Conservation agriculture in Europe. Int. Soil Water Conserv. Res. 2, 91-96. doi: 10.1016/S2095-6339(15)30016-2
Kibblewhite, M. G., Ritz, K., and Swift, M. J. (2008). Soil health in agricultural systems. Phil. Trans. R. Soc. B. 363, 685-701. doi: 10.1098/rstb.2007.2178

Kleijn, D., Kohler, F., Báldi, A., Batáry, P., Concepción, E. D., Clough, Y., et al. (2009). On the relationship between farmland biodiversity and land-use intensity in Europe. Proc. R. Soc. B. 276, 903-909. doi: 10.1098/rspb.2008.1509

Lehtinen, T., Schlatter, N., Baumgarten, A., Bechini, L., Krüger, J., Grignani, C., et al. (2014). Effect of crop residue incorporation on soil organic carbon and greenhouse gas emissions in European agricultural soils. Soil Use Manage. 30, 524-538. doi: 10.1111/sum.12151

Letey, J., Sojka, R. E., Upchurch, D. R., Cassel, D. K., Olson, K. R., Payne, W. A., et al. (2003). Deficiencies in the soil quality concept and its application. J. Soil Water Cons. 58, 180-187.

Loveland, P., and Webb, J. (2003). Is there a critical level of organic matter in the agricultural soils of temperate regions: a review. Soil Till. Res. 70, 1-18. doi: 10.1016/S0167-1987(02)00139-3

Luyssaert, S., Ciais, P., Piao, S. L., Schulze, E. D., Jung, M., et al. (2010). The European carbon balance. Part 3: forests. Glob. Change Biol. 16, 1429-1450. doi: $10.1111 / j .1365-2486.2009 .02056 . x$

McGeough, K. L., Laughlin, R. J., Watson, C. J., Mueller, C., Ernfors, M., Cahalan, E., et al. (2012). The effect of cattle slurry in combination with nitrate and the nitrification inhibitor dicyandiamide on in situ nitrous oxided and denitrogen emissions. Biogeosciences 9, 4909-4919. doi: 10.5194/bg-9-4909-2012

Metzger, M. J., Bunce, R. G. H., Jongman, R. H. G., Muecher, C. A., and Watkins, J. W. (2005). A climatic stratification of the environment of Europe. Global Ecol. Biogeogr. 14, 549-563. doi: 10.1111/j.1466-822X.2005.00190.x

Montanarella, L. (2007). "Trends in land degradation in Europe," in Climate and Land Degradation. eds M. V. K. Sivakumar and N. Ndiang'ui (Berlin/Heidelberg, Springer), 83-104. doi: 10.1007/978-3-540-72438-4_5

Mulvaney, R. L., Khan, S. A., and Ellsworth, T. R. (2009). Synthetic nitrogen fertilizers deplete soil nitrogen: a global dilemma for sustainable cereal production. J. Environ. Qual. 38, 2295-2314. doi: 10.2134/jeq2008.0527

Nevens, F., and Reheul, D. (2002). The nitrogen and non-nitrogen contribution effect of ploughed grass leys on the following arable forage crops: determination and optimum use. Eur. J. Agron. 16, 57-64. doi: 10.1016/S1161-0301(01)00115-0

O'Sullivan, L., Wall, D., Creamer, R., Bampa, F., and Schulte, R. (2018). Functional land management: bridging the think-do-gap using a multi-stakeholder science policy interface. Ambio 47, 216-230. doi: 10.1007/s13280-017-0983-x

Palma, R. M., Rimolo, M., Saubidet, M. I., and Conti, M. E. (1997). Influence of tillage system on denitrification in maize-cropped soils. Biol. Fert. Soils 25, 142-146. doi: 10.1007/s003740050294

Phalan, B. T. (2018). What have we learned from the land-sparing-sharing model? Sustainability 10:1760. doi: 10.3390/su10061760

Pilgrim, E. W., Macleod, C. J. A., Blackwell, M. S. A., Bol, R., Hogan, D. V., Chadwick, D. R., et al. (2010). Interactions among agricultural production and other ecosystem services delivered from European temperate grassland systems. Adv. Agron. 109, 117-154. doi: 10.1016/B978-0-12-385040-9.00004-9

Pittelkow, C. M., Liang, X., Linquist, B. A., van Groenigen, K. J., Lee, J., Lundy, M. E., et al. (2015). Productivity limits and potentials of the principles of conservation agriculture. Nature 517, 365-368. doi: 10.1038/nature13809

Power, A. G. (2010). Ecosystem services and agriculture: trade-offs and synergies. Philos. Trans. R. Soc. B. 365, 2959-2971. doi: 10.1098/rstb.2010.0143

Powlson, D. S., Jenkinson, D. S., Johnston, A. E., Pouton, P. R., Glendining, M. J., and Goulding, K. W. T. (2010). Comments on 'Synthetic nitrogen fertilizers deplete soil nitrogen: a global dilemma for sustainable cereal production', by R.L. Mulvaney, S.A. Khan, and T.R. Ellsworth in the Journal of Environmental Quality 2009 38:2295-2314. J. Env. Qual. 39, 749-752. doi: $10.2134 /$ jeq2010.0001le

Powlson, D. S., Whitmore, A. P., and Goulding, K. W. T. (2011). Soil carbon sequestration to mitigate climate change: a critical reexamination to identify the true and the false. Eur. J. Soil Sci. 62, 42-55. doi: $10.1111 / j .1365-2389.2010 .01342 . x$

Reijneveld, A., van Wensem, J., and Oenema, O. (2009). Soil organic carbon contents of agricultural land in The Netherlands between 1984 and 2004. Geoderma 152, 231-238. doi: 10.1016/j.geoderma.2009.06.007

Rochette, P., van Bochove, E., Prevost, D., Angers, D. A., Cote, D., and Bertrand, N. (2000). Soil carbon and nitrogen dynamics following application of pig slurry for the 19th consecutive year: II Nitrous oxide fluxes and mineral 
nitrogen. Soil Sci. Soc. Am. J. 64, 1396-1403. doi: 10.2136/sssaj2000.64 41396x

Rodriguez, N., McLaughlin, M., and Pennock, D. (2018). Soil Pollution: A Hidden Reality. (Rome: FAO), 142.

Russell, A. E., Cambardella, C. A., Laird, D. A., Jaynes, D. B., and Meek, D. W. (2009). Nitrogen fertilizer effects on soil carbon balances in Midwestern U.S. agricultural systems. Ecol. Appl. 19, 1102-1113. doi: 10.1890/07-1919.1

Sandén, T., Spiegel, A., Stüger, H. P., Schlatter, N., Haslmayr, H. P., Zavattaro, L., et al. (2018). European long-term field experiments: knowledge gained about alternative management practices. Soil Use Manage 34, 167-176. doi: 10.1111/sum.12421

Sanden, T., Trajanov, A., Spiegel, H., Kuzmanovski, V., Saby, N. P. A., Picaud, C., et al. (2019). Development of an agricultural primary productivity decision support model: a case study in France. Front. Environ. Sci. 7:58. doi: 10.3389/fenvs.2019.00058

Sandhu, H. S., Wratten, S. D., and Cullen, R. (2010). Organic agriculture and ecosystem services. Environ. Sci. Policy 13, 1-7. doi: 10.1016/j.envsci.2009.11.002

Schjønning, P., Lamandé, M., Thorsøe, M. H., and Frelih-Larsen, A. (2018). Policy Brief: Subsoil Compaction: A Threat to Sustainable Food Production and Soil Ecosystem Services. Recare EU FP7 ENV.2013.6.2-4, 8. Available online at: http://www.recare-hub.eu/case-studies/aarslev (accessed September $7,2020)$.

Schröder, J. J. (2005). Revisiting the agronomic benefits of manure: a correct assessment and exploitation of its fertilizer value spares the environment. Bioresource Tech. 92, 253-261. doi: 10.1016/j.biortech.2004.05.015

Schröder, J. J. (2014). The position of mineral nitrogen fertilizer in efficient use of nitrogen and land: a review. Nat. Resour. 5, 936-948. doi: 10.4236/nr.2014.515080

Schröder, J. J. (2019). "Circular agriculture: easier said than done. International Fertiliser Society” in Proceedings 834 (ISBN 978-0-85310-471-1), IFS Conference 12 December 2019, (Cambridge, UK), 22.

Schröder, J. J., Aarts, H. F. M., van Middelkoop, J. C., de Haan, M. H. A., Schils, R. L. M., Velthof, G. L., et al. (2007). Permissible manure and fertilizer use in dairy farming systems on sandy soils in The Netherlands to comply with the Nitrates Directive target. Eur. J. Agron. 27,102-114. doi: 10.1016/j.eja.2007.02.008

Schröder, J. J., Scholefield, D., Cabral, F., and Hofmans, G. (2004). The effects of nutrient losses from agriculture on ground and surface water quality: the position of science in developing indicators for regulation. Env. Sci. Pol. 7, 15-23. doi: 10.1016/j.envsci.2003.10.006

Schröder, J. J., Schulte, R. P. O., Creamer, R. E., Delgado, A., van Leeuwen, J., Lehtinen, T., et al. (2016). The elusive role of soil quality in nutrient cycling: a review. Soil Use Manage. 32, 476-486. doi: 10.1111/sum.12288

Schröder, J. J., Ten Holte, L., and Janssen, B. H. (1997). Non-overwintering cover crops: a significant source of N. Neth. J. Agric. Sci. 45, 231-248. doi: 10.18174/njas.v45i2.515

Schröder, J. J., van Dijk, W., and de Groot, W. J. M. (1996). Effects of cover crops on the nitrogen fluxes in a silage maize production system. Neth. J. Agric. Sci. 44, 293-315. doi: 10.18174/njas.v44i4.539

Schulte, R. P. O., Creamer, R. E., Donnellan, T., Farrelly, N., Fealy, R., O’Donoghue, C., et al. (2014). Functional land management: a framework for managing soil-based ecosystems services for the sustainable intensification of agriculture. Environ. Sci. Policy 38, 45-58. doi: 10.1016/j.envsci.2013. 10.002

Schulte, R. P. O., O’Sullivan, L., Vrebos, D., Bampa, F., Jones, A., and Staes, J. (2019). Demands on land: mapping competing societal expectations for the functionality of agricultural soils in Europe. Env. Sci. Policy 100, 113-125. doi: 10.1016/j.envsci.2019.06.011

Setälä, H., Berg, M. P., and Jones, T. H. (2005). Trophic structure and functional redundancy in soil communities. in Biological Diversity and Function in Soils, eds R. D. Bardgett, M. Usher, and D. Hopkins (Cambridge: Cambridge University Press), 236-249. doi: 10.1017/CBO9780511541926.014

Seufert, V., Ramankutty, N., and Foley, J. A. (2012). Comparing the yields of organic and conventional agriculture. Nature 485, 229-232. doi: 10.1038/nature11069

Soane, B. D., and Van Ouwerkerk, C. (1995). Implications of soil compaction in crop production for the quality of the environment in Soil Till. Res. 35, 5-22. doi: 10.1016/0167-1987(95)00475-8
Sojka, R. E., Upchurch, D. R., and Borlaug, N. E. (2003). Quality soil management or soil quality management: performance vs semantics. Adv. Agron. 79, 1-68. doi: 10.1016/S0065-2113(02)79001-9

Spiegel, H., Schlatter, N., Haslmayr, H. P., Lehtinen, T., and Baumgarten, A. (2014). Impacts of Soil Management on Indicators for Climate Change Mitigation. ed H. F. M. Ten Berge (Vienna: AGES) CATCH-C Report D3.334. 57 p.

Spiegel, A., Sandén, T., Dersch, G., Baumgarten, A., Gründling, R., and Franko, U. (2018). Soil "Organic matter and nutrient dynamics following different management of crop residues at two sites in Austria," in Soil Management and Climate Change, 253-265. doi: 10.1016/B978-0-12-812128-3.00017-3

Stoate, C., Báldi, A., Beja, P., Boatman, N. D., Herzon, I., van Doorn, A., et al. (2009). Ecological impacts of early 21st century agricultural change in Europe: a review. J. Environ. Manage. 91, 22-46. doi: 10.1016/j.jenvman.2009.07.005

Stolte, J., Tesfai, M., Øygarden, L., Kværn,ø, S., Keizer, J., Verheijen, F., et al. (2016). "Soil threats in Europe: status, methods, drivers and effects on ecosystem services," in JRC Technical Reports (Ispra: JRC European Soil Data Centre), 206.

Stürck, J., and Verburg, P. H. (2017). Multifunctionality at what scale? A landscape multifunctionality assessment for the European Union under conditions of land use change. Landscape Ecol. 32, 481-500. doi: 10.1007/s10980-016-0459-6

Sturel, S., Bampa, F., Sandén, T., Spiegel, H., Madena, K., Brunet, A., et al. (2018). "Report on optimised suits of soil functions, as prioritized by stakeholder groups," in Landmark (H2020-SFS-2014-2), Deliverable 1.2 (Bruxelles: European Commission), 60.

Ten Berge, H. F. M., Schröder, J. J., Olesen, J. E., and Giraldez Cervera, J. V. (2017). "Preserving agricultural soils in the EU: an in depth analysis," in Study Assigned by the European Parliament IP/B/AGRI/IC/2016-138, Directorate-General for internal policies (Bruxelles: Policy Department for Structural and Cohesion Policies), 103.

Ten Berge, H. F. M., Schröder, J. J., Olesen, J. E., and Giraldez Cervera, J. V. (2019). "Soil quality: a confusing beacon for sustainability," in International Fertiliser Society Proceedings 841, IFS Conference 12 December 2019 (Cambridge), 64.

Thompson, R. B. (1989). Denitrification in slurry-treated soil: occurrence at low temperatures, relationship with soil nitrate and reduction by nitrification inhibitors. Soil Biol. Biochem. 21, 875-882. doi: 10.1016/0038-0717(89) 90075-8

Trajanov, A., Schröder, J. J., Wall, D., Delgado, A., Schulte, R. P. O., and Debeljak, M. (2019). “Assessing the nutrient cycling potential in agricultural soils using decision modelling," in Proceedings Conference on Operational Research, September 2019 (Bled). Available online at: http://fgg-web.fgg.unilj.si/ /sdrobne/sor/SOR'19\%20-\%20Proceedings.pdf (accessed September 7, 2020).

Tsiafouli, M., Thebault, E., Sgardelis, P., de Ruiter, van der Putten, P. C. (2015). Intensive agriculture reduces soil biodiversity across Europe. Glob. Change Biol. 21, 973-985. doi: 10.1111/gcb.12752

Valbuena, D., Erenstein, O., Homann, S., Abdoulaye, T., Claessens, L., Duncahn, A. J., et al. (2012). Conservation agriculture in mixed crop-livestock systems: scoping crop residue trade-offs in Sub-Saharan Africa and South Asia. Field Crops Res. 132, 175-184. doi: 10.1016/j.fcr.2012.02.022

van de Broek, M., Bugge Henriksen, C., Ghaley, B. B., Lugato, E., Kuzmanovski, V., Trajanov, A., et al. (2019). Assessing the climate regulation potential of agricultural soils using a decision support tool adapted to stakeholders' needs and possibilities. Front. Environ. Sci. 7, 131. doi: 10.3389/fenvs.2019. 00131

van den Bossche, A., de Bolle, S., de Neve, S., and Hofman, G. (2009). Effect of tillage intensity on $\mathrm{N}$ mineralization of different crop residues in a temperate climate. Soil Till. Res. 103, 316-324. doi: 10.1016/j.still.2008.10.019

van den Broeck, G., Romero Perez Grovas, R., Maertens, M., Deckers, J., Verhulst, N., and Govaerts, B. (2013). Adoption of conservation agriculture in the Mexican Bajío. Agriculture 42, 171-178. doi: 10.5367/oa.2013.0136

van den Putte, A., Govers, G., Diels, J., Gillijns, K., and Demuzere, M. (2010). Assessing the effect of soil tillage on crop growth: a meta-regression analysis on European crop yields under conservation agriculture. Eur. J. Agron. 33, 231-241. doi: 10.1016/j.eja.2010.05.008

van Dyck, H., van Strien, A. J. Maes, D., and van Swaay, C. A. (2009). Declines in common, widespread butterflies in a landscape under intense human use. Conserv. Biol. 23, 957-965. doi: 10.1111/j.1523-1739.2009.01175.x

van Leeuwen, J., Creamer, R. E., Cluzeau, D., Debeljak, M., Gatti, F., Bugge Henriksen, C., et al. (2019). Modeling of soil functions for assessing soil 
quality: soil biodiversity and habitat provisioning. Front. Environ. Sci. 22:113. doi: 10.3389/fenvs.2019.00113

van Zanten, H. H. E., van Ittersum, M. K., and de Boer, I. J. M. (2019). The role of farm animals in a circular food system. Global Food Security 21, 18-22. doi: 10.1016/j.gfs.2019.06.003

Veerman, C., Pinto Correia, T., Bastioli, C., Biro, B., Bouma, J., Cienciela, E., et al. (2020). Caring For Soil is Caring for Life. Interim Report for the Mission Board for Soil Health and Food (Brussels: European Commission), 52.

Velthof, G. L., Kuikman, P. J., and Oenema, O. (2003). Nitrous oxide emission from animals manures applied to soil under controlled conditions. Biol. Fertil. Soils 37, 221-230. doi: 10.1007/s00374-0030589-2

Virto, I., Imaz, M. J., Fernandez-Uglade, O., Gartzia-Bengoetxea, N., Enrique, A., and Bescansa, P. (2015). Soil degradation and soil quality in WesternEurope: current situation and future perspectives. Sustainability 7, 313-365. doi: $10.3390 /$ su7010313

Vos, J., and van der Putten, P. E. L. (1997). Field observations on nitrogen catch crops. I. Potential and actual growth and nitrogen accumulation in relation to sowing date and crop species. Plant Soil 195, 299-309. doi: 10.1023/A:1004281218996
Vrebos, D., Bampa, F., Creamer, R. E., Gardi, C., Ghaley, B. B., Jones, A., et al. (2017). The impact of policy instruments on soil multifunctionality in the European Union. Sustainability 9:407. doi: 10.3390/su9030407

Wall, D. P., Delgado, A., O’Sullivan, L., Creamer, R.E., Trajanov, A., Kuzmanovski, V., et al. (2020). A decision support model for assessing the water regulation and purification potential of agricultural soils across Europe. Front. Sustain. Food Syst. 4: 115 doi: 10.3389/fsufs.2020.00115

Conflict of Interest: The authors declare that the research was conducted in the absence of any commercial or financial relationships that could be construed as a potential conflict of interest.

Copyright (c) 2020 Schröder, Ten Berge, Bampa, Creamer, Giraldez-Cervera, Henriksen, Olesen, Rutgers, Sandén and Spiegel. This is an open-access article distributed under the terms of the Creative Commons Attribution License (CC BY). The use, distribution or reproduction in other forums is permitted, provided the original author(s) and the copyright owner(s) are credited and that the original publication in this journal is cited, in accordance with accepted academic practice. No use, distribution or reproduction is permitted which does not comply with these terms. 